\title{
PEMANFAATAN WEBSITE DALAM UPAYA MENINGKATKAN KEAKTIFAN SISWA DALAM PEMBELAJARAN MATEMATIKA
}

\author{
Erna Puji Astutik ${ }^{1}$, Hanim Faizah ${ }^{2}$, Prayogo $^{3}$ \\ 1, 2,3 Dosen Program Studi Pendidikan Matematika \\ FKIP Universitas PGRI Adi Buana Surabaya \\ Email : ${ }^{1}$ ernamzduta@gmail.com, ${ }^{2}$ hanim06b@gmail.com, ${ }^{3}$ prayogounipa@gmail.com,
}

\begin{abstract}
The purpose of this research is to provide solutions based on the analysis of the situation conducted on two schools, they are SD Islam Wahid Hasyim and MI Ma'arif Kedensari Sidoarjo conducted through: 1) socialization for teachers in the two schools about the use of website in learning mathematics. In this case the website to be used is a website launched by NCTM which can be accessed through http://illuminations.nctm.org; 2) training for teachers in the two schools on website utilization in mathematics learning; and 3) mentoring the teachers from the two schools in using the website in teaching mathematics. This research includes three main stages, they are planning, implementation, and assessment. The results obtained from this research is that most teachers are able to operate computers, use the internet, access NCTM websites, and run interactive media in the website. Teachers are also able to utilize the NCTM website as a media in teaching mathematics. There is an increase in student activity in learning mathematics by using the website in SD Islam Wahid Hasyim and MI Ma'arif Kedensari that is relevant to the teaching and learning activities increased from $70 \%$ to $85 \%$ and from $69 \%$ to $81 \%$. Most students feel happy with the mathematics learning by using the website, students can use the media on the website and understand the material taught through the media, and students do not have difficulty in learning mathematics by using the website.
\end{abstract}

Keywords: mathematics learning, website, student activity

\section{PENDAHULUAN}

Lokasi Kabupaten Sidoarjo, sekitar $25 \mathrm{~km}$ dari kota Surabaya. Lokasi sekolah-sekolah tersebut khususnya Sekolah Dasar (SD)/Madrasah Ibtidaiyah (MI), sebagian besar terletak di daerah pedesaan sehingga para guru jarang terlibat dalam kegiatan-kegiatan ilmiah yang dilakukan oleh Perguruan Tinggi. Selain itu sebagian besar guru SD/MI kurang memanfaatkan media dalam proses pembelajaran. Berdasarkan hasil wawancara dengan beberapa guru dan kepala sekolah di SD Islam Wahid Hasyim dan MI Ma'arif Kedensari Sidoarjo yang dilakukan pada bulan Mei 2016, diperoleh informasi bahwa, pembelajaran matematika yang dilaksanakan selama ini sangat jarang menggunakan media, baik berupa alat peraga ataupun media-media inovatif lainnya. Siswa belajar matematika lebih banyak melalui penjelasan secara langsung oleh guru yang didominasi dengan pemberian ceramah. Sebagai 
akibatnya siswa cenderung menghafal konsep atau prosedur matematis tertentu sehingga pembelajaran matematika yang dilaksanakan kurang bermakna. Hal ini berdampak pada pembelajaran matematika berlangsung dengan membosankan.

Siswa SD berada pada tahap berpikir operasional konkret sehingga masih terikat dengan objek yang ditangkap dengan pancaindra (Heruman, 2008). Oleh karena itu, guru diharapkan memanfaatkan media ataupun alat peraga dalam pembelajaran matematika yang bersifat abstrak. Media pembelajaran maupun alat peraga dapat memperjelas apa yang disampaikan oleh guru sehingga siswa akan lebih cepat memahami materi. Untuk mengoptimalkan pembelajaran di kelas, guru juga dapat memanfaatkan kemajuan teknologi yang berkembang saat ini yaitu salah satunya dengan mengintegrasikan website dalam pembelajaran matematika. Penggunaan teknologi dalam pembelajaran memungkinkan berlangsungnya proses pembelajaran secara individu (individual learning) yang dapat menumbuhkan kemandirian pada siswa dalam pembelajaran dimana siswa dapat mengulang kembali materi yang belum dipahami dengan melakukan latihan secara mandiri melalui aplikasi yang ada pada website.

Penelitian oleh Patahuddin (2009) di Sekolah Dasar di Australia tentang pemanfaatan internet untuk pembelajaran dan pengajaran matematika, menunjukkan bahwa penggunaan internet dapat memperkaya pembelajaran matematika siswa dan membantu guru melayani kebutuhan belajar siswa yang berbeda-beda. Selain itu, Rokhmah (2009) dalam penelitiannya tentang pembelajaran matematika menggunakan website di salah satu RSBI di Sidoarjo memberikan indikasi positif. Meskipun siswa tampak kesulitan dalam aspek bahasa tetapi banyak siswa yang antusias dalam belajar matematika dengan website tersebut. Hal ini dikarenakan, mereka dapat belajar sekaligus dua hal, yaitu bahasa Inggris dan matematika. Selain itu, animasi pada website merupakan tambahan variasi dalam belajar matematika. Para siswa tersebut juga mengakui bahwa belajar matematika dengan menggunakan internet merupakan hal yang baru dan menyenangkan.

Mempertimbangkan pemahaman yang masih kurang dalam desain pembelajaran, khususnya dalam memanfaatkan website/internet dalam pembelajaran, maka para guru dan kepala sekolah bersama dengan pelaksana IbM (Ipteks bagi Masyarakat) memandang perlu untuk mengadakan kegiatan IbM yang melibatkan para guru di dua sekolah mitra tersebut. Para guru dan kepala sekolah sangat antusias ketika pelaksana IbM ini menyampaikan suatu solusi berupa pelatihan pemanfaatan website dalam pembelajaran matematika. Hal ini karena mereka memandang sangat memerlukan 'penyegaran' terkait dengan pembelajaran berbasis website agar dapat mengembangkan kemampuan profesionalisme mereka yang bermuara pada peningkatan kualitas hasil belajar matematika siswa.

Kegiatan IbM ini dilakukan pada guru di SD Islam Wahid Hasyim dan MI Ma'arif Kedensari Sidoarjo. Para guru yang dilibatkan dari dua sekolah ini akan diminta untuk mengimplementasikan pembelajaran berbasis website pada kelasnya masing-masing di bawah bimbingan tim pelaksana kegiatan IbM. Melalui kegiatan ini, diharapkan dapat memotivasi para guru untuk berinovasi dalam melaksanaan pembelajaran matematika khususnya dengan memanfaatkan website sehingga dapat memfasilitasi siswa dalam belajar matematika dengan lebih mudah dan menyenangkan. 


\section{METODE PELAKSANAAN}

Pelaksanaan IbM ini meliputi tiga tahap yaitu tahap perencanaan, tahap pelaksanaan, dan tahap penilaian. Pada tahap perencanaan, kegiatan yang dilakukan meliputi: merumuskan tujuan dan tema kegiatan, menganalisis kebutuhan guru dalam pembelajaran matematika, menganalisis kesesuaian materi dengan aplikasi yang terdapat di website, merumuskan strategi pembelajaran, menganalisis kebutuhan sumber belajar, dan merancang jadwal pelaksanaan pelatihan dan pendampingan.

Pada tahap pelaksanaan, kegiatan yang dilakukan adalah sebagai berikut.

a. Mengadakan sosialisasi bagi guru di sekolah mitra tentang pemanfaatan website dalam pembelajaran matematika. Dalam hal ini salah satu website yang akan digunakan adalah website yang diluncurkan oleh NCTM yang bisa diakses melalui http://illuminations.nctm.org.

b. Mengadakan pelatihan bagi guru di sekolah mitra tentang pemanfaatan website dalam pembelajaran matematika.

c. Mengadakan pendampingan guru mitra dalam memanfaatkan atau menggunakan website dalam pembelajaran matematika kepada peserta didik.

Sedangkan pada tahap penilaian, halhal yang dinilai meliputi: penilaian kemampuan guru, penilaian aktivitas siswa, dan penilaian keberhasilan website dalam pembelajaran matematika

\section{HASIL DAN PEMBAHASAN}

\section{a. Sosialisasi IbM Pemanfaatan Website dalam Pembelajaran Matematika}

Pelaksana mengadakan sosialisasi bagi guru di sekolah mitra tentang pemanfaatan website dalam pembelajaran matematika. Dalam hal ini website yang digunakan adalah website yang diluncurkan oleh NCTM yang bisa diakses melalui http://illuminations.nctm.org. Kegiatan sosialisasi ini dilaksanakan sebanyak dua kali di tempat yang berbeda sesuai dengan lokasi mitra yaitu di MI Ma'arif Kedensari Sidoarjo yang dilaksanakan pada tanggal 15 Juni 2017 dan di SD Islam Wahid Hasyim Sidoarjo yang dilaksanakan pada tanggal 17 Juni 2017.

Pada kegiatan sosialisasi ini para guru di sekolah mitra dikenalkan website dari NCTM yang dapat digunakan dalam pembelajaran matematika serta beberapa contoh pemanfaatan aplikasi yang terdapat di website tersebut.

\section{b. Pelatihan IbM Pemanfaatan Website dalam Pembelajaran Matematika}

Setelah pelaksanaan sosialisasi, pelaksana mengadakan pelatihan bagi guru di sekolah mitra tentang pemanfaatan website NCTM dalam pembelajaran matematika pada tanggal 19 Juli 2017 yang bertempat di MI Ma'arif Kedensari Sidoarjo dan pada tanggal 22 Juli 2017 yang bertempat di SD Islam Wahid Hasyim Sidoarjo.

Pelaksaan pelatihan ini mendapat sambutan yang baik dari kedua sekolah mitra terbukti dari jumlah guru matematika di SD Islam Wahid Hasyim Sidoarjo yang hanya 12 guru tetapi pada pelaksaan pelatihan diikuti oleh 14 guru karena permintaan sekolah. Begitu juga dengan pelaksanaan pelatihan di MI Ma'arif Kedensari Sidoarjo yang tidak hanya diikuti oleh guru matematika yang berjumlah 9 guru tetapi diikuti oleh seluruh guru MI Ma'arif Kedensari Sidoarjo yang berjumlah 14 guru. Pada saat pelatihan, para guru antusias mengikuti intruksi dan mencoba setiap aplikasi pada website yang diperkenalkan oleh pelaksana. Selain itu, para guru diberi kesempatan untuk memilih dan mencoba sendiri aplikasi pada website NCTM yang sesuai dengan materi pembelajaran di kelas masing-masing. 
c. Pendampingan IbM Pemanfaatan

Website dalam Pembelajaran Matematika

Kegiatan pendampingan dilaksanakan di kedua sekolah mitra yaitu di MI Ma'arif Kedensari Sidoarjo dan SD Islam Wahid Hasyim Sidoarjo. Pada kegiatan pendampingan, guru mitra melaksanakan pembelajaran matematika

Tabel 1: Jadwal Pendampingan IbM Pemanfaatan Website dalam Pembelajaran Matematika

\begin{tabular}{|l|l|l|}
\hline \multicolumn{1}{|c|}{ Pendampingan } & \multicolumn{1}{|c|}{ Tanggal } & \multicolumn{1}{c|}{ Tempat } \\
\hline Pendampingan 1 & $19-09-2017$ & $\begin{array}{l}\text { SD Islam Wahid Hasyim } \\
\text { Sidoarjo }\end{array}$ \\
\hline Pendampingan 2 & $27-09-2017$ & $\begin{array}{l}\text { SD Islam Wahid Hasyim } \\
\text { Sidoarjo }\end{array}$ \\
\hline Pendampingan 3 & $30-09-2017$ & $\begin{array}{l}\text { SD Islam Wahid Hasyim } \\
\text { Sidoarjo }\end{array}$ \\
\hline Pendampingan 4 & $\begin{array}{l}\text { MI Ma'arif Kedensari } \\
\text { Sidoarjo }\end{array}$ \\
\hline Pendampingan 5 & $03-10-2017$ & $\begin{array}{l}\text { MI Ma'arif Kedensari } \\
\text { Sidoarjo }\end{array}$ \\
\hline Pendampingan 6 & $05-10-2017$ & $\begin{array}{l}\text { MI Ma'arif Kedensari } \\
\text { Sidoarjo }\end{array}$ \\
\hline
\end{tabular}

\section{d. Penilaian Pelaksanaan IbM}

Pada kegiatan IbM ini dilakukan penilaian pada saat kegiatan pelatihan dan pendampingan yang meliputi penilaian kemampuan guru, penilaian aktivitas siswa, dan penilaian keberhasilan website dalam pembelajaran matematika yang dijelaskan berikut.

\section{1) Kemampuan Guru Memanfaatkan Website dalam Pembelajaran Matematika}

Berdasarkan observasi diperoleh hasil bahwa kemampuan guru selama pelatihan di SD Islam Wahid Hasyim sangat baik. Sebagian besar guru di sekolah tersebut mampu mengoperasikan komputer, menggunakan internet, mengakses website NCTM, serta menjalankan media interaktif dalam website tersebut dengan baik. Akan tetapi, ada satu guru yang memiliki kemampuan kurang dalam mengoperasikan komputer, menggunakan dengan memanfaatkan website NCTM dengan didampingi oleh pelaksana IbM. Kegiatan pendampingan ini dilaksanakan oleh tim guru matematika maupun guru kelas yang bertanggungjawab mengajar matematika di kelas 1 sampai kelas 6 sesuai jadwal dalam tabel berikut.

internet serta mengakses website pada saat pelatihan yang membutuhkan arahan dari pelaksana IbM dan mahasiswa, begitu juga pada saat menjalankan media interaktif dalam website.

Hasil observasi yang dilakukan selama pelatihan di MI Ma'arif Kedensari tidak jauh berbeda dengan SD Islam Wahid Hasyim. Sebagian besar guru mampu mengoperasikan komputer, menggunakan internet, mengakses website NCTM, serta menjalankan media interaktif dalam website tersebut hanya saja jumlah guru yang kemampuannya sangat baik lebih sedikit bila dibandingkan dengan SD Islam Wahid Hasyim. Guru-guru di MI Ma'arif Kedensari juga membutuhkan arahan dari pelaksana IbM dan mahasiswa saat menggunakan internet, mengakses website, serta menjalankan aplikasi yang terdapat dalam website tersebut.

Selain pada saat pelatihan, kemampuan guru juga dilihat pada saat pendampingan yaitu kemampuan guru 
pada saat mengajar matematika dengan memanfaatkan website NCTM. Kemampuan guru pada saat pendampingan di SD Islam Wahid Hasyim sebagian besar dalam kategori sangat baik dalam artian guru mampu memanfaatkan website NCTM sebagai media dalam pembelajaran matematika. Akan tetapi guru masih kesulitan dalam menentukan media/aplikasi pada website yang sesuai dengan materi matematika yang diajarkan karena Bahasa pengantar yang dipakai dalam website adalah Bahasa inggris. Begitu juga dengan kemampuan guru di MI Ma'arif Kedensari yang tidak jauh berbeda dengan SD Islam Wahid Hasyim. Para guru mampu memanfaatkan website NCTM dalam pembelajaran matematika, akan tetapi masih terkendala Bahasa pengantar yang ada pada website.

\section{2) Aktivitas Siswa dalam Pembelajaran Matematika dengan Memanfaatkan Website}

Berdasarkan hasil observasi dapat dijelaskan bahwa terdapat peningkatan aktivitas siswa dalam pembelajaran matematika di SD Islam Wahid Hasyim dengan memanfaatkan website yaitu aktivitas yang relevan dengan KBM meningkat dari $70 \%$ menjadi $85 \%$. Hal ini terjadi juga di MI Ma'arif Kedensari, aktivitas siswa yang relevan dengan KBM meningkat dari $69 \%$ menjadi $81 \%$.

\section{3) Keberhasilan Website dalam Pembelajaran Matematika}

Setelah pendampingan yang dilakukan diperoleh hasil bahwa sebagian besar siswa di SD Islam Wahid Hasyim merespon dengan baik pembelajaran matematika dengan memanfaatkan website. Sebanyak 98,29\% siswa merasa senang dengan pembelajaran matematika dengan memanfaatkan website, 94,29\% siswa bisa menggunakan media yang terdapat pada website dan memahami materi yang diajarkan melalui media tersebut, serta $74,29 \%$ siswa tidak mengalami kesulitan dalam pembelajaran matematika dengan memanfaatkan website. Berdasarkan hasil angket diperoleh jawaban siswa yang masih mengalami kesulitan dikarenakan beberapa kali koneksi listrik terputus serta koneksi internet yang kurang cepat sehingga beberapa kelompok siswa harus menunggu atau mengulang lagi dari awal.

Respon yang positif terhadap pembelajaran matematika dengan memanfaatkan website juga diperoleh dari siswa di MI Ma'arif Kedensari. Sebanyak 96,11\% siswa merasa senang dengan pembelajaran matematika dengan memanfaatkan website, $87,22 \%$ siswa bisa menggunakan media yang terdapat pada website, $90 \%$ siswa memahami materi yang diajarkan melalui media tersebut, dan $79,44 \%$ siswa tidak mengalami kesulitan dalam pembelajaran matematika dengan memanfaatkan website. Beberapa siswa yang masih mengalami kesulitan diketahui dari hasil angket dan wawancara dengan guru kelas karena beberapa siswa belum lancar membaca terutama pada siswa kelas satu.

Selain respon siswa, respon guru juga digunakan untuk menilai keberhasilan website dalam pembelajaran matematika. Setelah kegiatan pendampingan diperoleh respon yang positif dari guru. Menurut para guru pembelajaran matematika dengan memanfaatkan website sangat menyenangkan, siswa terlihat aktif dan antusias dalam pelajaran, serta membantu siswa dalam belajar sambil bermain. Website tersebut juga dapat dimanfaatkan oleh guru sebagai media pembelajaran.

Menurut para guru terdapat perbedaan antara pembelajaran matematika biasa dan dengan memanfaatkan website dimana siswa lebih tertarik dengan matematika, tidak mengalami kejenuhan karena pembelajaran yang bervariasi, serta lebih ingin tahu mencoba terus sampai mereka bisa. 
Selain kelebihan pembelajaran matematika dengan memanfaatkan website di atas, terdapat juga kekurangan yaitu beberapa siswa yang mengalami kesulitan dalam mengoperasikan komputer, koneksi internet yang kurang cepat, masih ada siswa kelas satu yang belum bisa membaca, dan Bahasa pengantar pada website yang digunakan adalah Bahasa Inggris yang membuat siswa kesulitan. Sedangkan kendala yang dihadapi oleh guru adalah beberapa guru masih kesulitan menentukan permainan karena Bahasa pengantar website dalam Bahasa Inggris. Oleh karena itu pelaksana mengembangkan buku ajar yang berupa buku petunjuk untuk mengakses website dan aplikasi yang terdapat pada website. Selain itu juga buku petunjuk akan dilengkapi dengan beberapa kata kunci Bahasa Inggris yang diterjemahkan ke dalam Bahasa Indonesia.

Secara keseluruhan kegitan IbM pemanfaatan website dalam pembelajaran matematika dapat dikatakan berhasil dengan kemampuan guru yang baik dalam memanfaatkan website dalam pembelajaran matematika serta adanya peningkatan aktivitas siswa dalam pembelajaran matematika.

\section{KESIMPULAN}

Adapun kesimpulan yang diperoleh selama kegiatan IbM yang telah dilakukan adalah sebagai berikut.

a. Kegiatan sosialisasi dan pelatihan pemanfaatan website dalam pembelajaran matematika berjalan dengan baik dan mendapat respon positif dari sekolah mitra yaitu SD Islam Wahid Hasyim dan MI Ma'arif Kedensari.

b. Sebagian besar guru mampu mengoperasikan komputer, menggunakan internet, mengakses website NCTM, serta menjalankan media interaktif dalam website tersebut. Guru juga mampu memanfaatkan website NCTM sebagai media dalam pembelajaran matematika. Akan tetapi guru masih kesulitan dalam menentukan media/aplikasi pada website yang sesuai dengan materi matematika yang diajarkan karena Bahasa pengantar yang dipakai dalam website adalah Bahasa inggris.

c. Terdapat peningkatan aktivitas siswa dalam pembelajaran matematika dengan memanfaatkan website di SD Islam Wahid Hasyim dan MI Ma'arif Kedensari yaitu aktivitas yang relevan dengan $\mathrm{KBM}$ meningkat dari $70 \%$ menjadi $85 \%$. dan dari $69 \%$ menjadi $81 \%$.

d. Sebagian besar siswa merasa senang dengan pembelajaran matematika dengan memanfaatkan website, siswa bisa menggunakan media yang terdapat pada website dan memahami materi yang diajarkan melalui media tersebut, serta siswa tidak mengalami kesulitan dalam pembelajaran matematika dengan memanfaatkan website.

e. Seluruh guru dapat memanfaatkan website dalam pembelajaran matematika dengan baik.

\section{DAFTAR PUSTAKA}

Gibson, S., \& Oberg, D. 2004. Visions and realities of Internet use in schools: Canadian perspectives. British Journal of Educational Technology, 35(5), 569-585.

Heruman. 2008. Model pembelajaran matematika di sekolah dasar. Bandung: Remaja Rosda Karya

Patahuddin, S. M. 2009. Exploiting the Internet for Teacher Professional Development and Mathematics Teaching and Learning: An Ethnographic Intervention. 
Disertasi. Brisbane: The

University of Queensland.

Patahuddin, S. M., Rohmah, S., \& Nur,

M. 2009. Pengembangan LKS

Berbasis ICT pada

Pembelajaran Matematika SMP

RSBI. Prosiding Seminar

Nasional Matematika dan

Pendidikan Matematika Jurusan

Pendidikan Matematika FMIPA

UNY.

Rokhmah, S. 2009. Pembelajaran Matematika dengan

Menggunakan Internet di

Rintisan Sekolah Bertaraf

Internasional (RSBI). Skripsi.

Surabaya: Universitas Negeri

Surabaya.

http://illuminations.nctm.org 
ABADIMAS ADI BUANA Volume 02, Nomer 2, 01 Oktober 2017 